\title{
ОСНОВНІ ПІДХОДИ ДО РОЗВ'ЯЗАННЯ ПРОБЛЕМИ ФОРМУВАННЯ ПІЗНАВАЛЬНОЇ САМОСТІЙНОСТІ ВЧИТЕЛЯ
}

У статті здійснено спробу проаналізувати найпоширеніші підходи до розв'язання проблеми формування пізнавальної самостійності вчителя, які виокремлюються на основі зіставлення мети пізнавальної діяльності вчителя, способів ї̈ досягнення та отриманого результату.

Ключові слова: самостійна робота, пізнавальна самостійність, навчально-пізнавальна діяльність, самоосвіта.

В статье сделана попытка проанализировать наиболее распространенные подходы к решению проблемы формирования познавательной самостоятельности учителя, которые выделяются на основе сопоставления цеели познавательной деятельности учителя, способов ее достижения и полученного результата.

Ключевые слова: самостоятельная робота, познавательная самостоятельность, учебно-познавательная деятельность, самообразование.

The article is devoted to the attempts of analyzing of the most common approaches to solving the problem of formation of teachers' cognitive independence which are allocated based on a comparison of the cognitive objectives of the teacher, the ways to achieve it and the result.

Key words: independent work, cognitive independence, educationalcognitive activity, self-education.

Проблема розвитку та формування пізнавальної самостійності індивіда $є$ давно усвідомленою широким педагогічним загалом. Розв'язати цю проблему філософи, педагоги, психологи намагалися, ураховуючи різні методологічні позиції.

Mema cmammi - проаналізувати найпоширеніші підходи до розв'язання проблеми формування пізнавальної самостійності вчителя, які виокремлюються на основі зіставлення цілі пізнавальної діяльності вчителя, способів ії досягнення та отриманого результату.

Перший підхід до розв'язання проблеми формування пізнавальної самостійності вчителя умовно можна визначити як емпірико-ситуативний.

Накопичення досвіду організації та здійснення навчальної діяльності призвело до усвідомлення існування спільних закономірностей пізнання людиною навколишнього світу та 
процесу навчання. Думка про необхідність спеціального керівництва процесом розвитку пізнавальної самостійності не лише учнів, а й педагога виникає в античні часи. Цю думку висловлює грецький філософ Сократ. Він одним із перших зазначив, що освіта повинна грунтуватися на пізнанні людини. Справжня освіта, яка може вдосконалити людину, повинна передбачати інтериорізацію набутих уявлень і знань, які набуває людина протягом життя. Посправжньому формувальний характер має те навчання, яке спонукає людину до самостійних роздумів. Спонукальне до мудрості навчання повинно допомагати тому, хто навчається, самому формувати свої знання. Сократ був переконаний, що до здійснення процесу навчання необхідно готуватися завчасно, зокрема, попередньо готувати завдання й запитання до співрозмовника. Він уперше розробив і використав власний метод навчання - маєвтику, складовою частиною цього методу була евристична бесіда, побудована на основі використання прийомів індукції. Метод Сократа спрямовувався на розвиток пізнавальної самостійності індивіда; на думку філософа, пізнання $є$ сутністю людського життя, цей процес слід звільнити від негативних зовнішніх впливів i забезпечити гармонійну єдність життєвих потреб і здібностей людини, які, у свою чергу, розвиваються інтересом до знань. Філософ розглядав пізнавальну самостійність своїх учнів як результат доцільного впливу педагога, що сам має відповідну якість.

В окремих філософських працях Арістотеля, Антисфена, Ксенофонта, Платона ми знаходимо думки про те, як організувати самопізнання інших і вимоги до тих, хто має цьому навчати.

У трактатах давньоримських філософів, зокрема, М. Квінтіліана [3], також містяться глибокі думки про надзвичайно важливу роль учителя у засвоєнні знань учнями у процесі розвитку пізнавальної самостійності. Для цього потрібно заохочувати постановку запитань учнів до вчителя, організовувати обмін думками, дискусії, формувати навички самостійного пізнання. М. Квінтіліан, формулюючи поради для майбутнього вчителя, пише про те, що він повинен викладати просто, бути терплячим у роботі, бути більш дбайливим, ніж вимогливим, «нехай він охоче відповідає тим, хто питає, і нехай ставить питання мовчазним» [3, c. 56]. Учитель повинен працювати над виробленням 
відповідних професійних якостей, наприклад, пам'яті: «дехто вважає, що пам'ять є лише дар природи. Без сумніву, від природи в цьому випадку багато залежить, але все ж пам'ять, як природний хист, може зміцнюватися завдяки культурі в кожному віці. Той, хто візьме на себе роботу розвинути пам'ять за допомогою занять, повинен спершу відтворити у пам'яті написане й прочитане» [3, с. 57].

Заклик до вчителя йти шляхом самопізнання, самозанурення у світ інтелектуальний і духовний міститься у працях педагогів, письменників, громадських діячів епохи пізнього Середньовіччя (Відродження), - М. Монтеня, Ф. Рабле, Т. Мора. Педагоги-дослідники відзначають той факт, що у філософських трактатах формулюється вимога до філософавчителя постійно працювати над собою й осягнути сутність речей і пізнання власними інтелектуальними зусиллями.

У межах окресленого підходу присутне розуміння того, що вчитель повинен працювати над собою та виробляти відповідні якості, які умовно можна віднести до якостей пізнавальної самостійності.

Другий підхід - утилітарно-функціональний. Він пов'язаний із усвідомленням практичної корисності розвитку пізнавальної самостійності індивіда. Цей підхід представлений науковими здобутками тих педагогів, які вбачають у пізнавальній самостійності необхідну якість соціалізації особистості та передумову успішної особистісно-індивідуальної, професійної самореалізації. Свого часу Й. Ратке саму дидактику розглядав як мистецтво навчання, свого роду «практичне вміння» у пізнанні дитиною навколишнього світу, а швейцарський педагог Й. Песталоцці одним із перших довів «необхідність вивчення психіки індивіда 3 дидактичною метою», саме на цій основі розробивши теорію елементарної освіти. Послідовник швейцарського педагога А. Дістервег у праці «Посібник для освіти німецьких учителів» цілком свідомо висуває вимогу розвитку пізнавальної самостійності педагога й підкреслює їі значення для успішного здійснення навчального процесу: «Освіта ніколи й ніде не була чимось закінченим і завершеним. Вона знаходилася в становленні й у зміні, чого не можна собі уявити без діяльності, руху, росту. Якщо правильно, що освіта інших полягає переважно в їх збудженні, а це збудження залежить від самодіяльності того, хто збуджує, то звідси випливає, що подібне навчання для самого вчителя $є$ школою самоосвіти у вищому розумінні 
слова. Оскільки вчитель більшу частину дня займається навчанням, то його подальша власна освіта повинна йому даватися легше, ніж решті людей, за умови, що його навчання дійсно є збудженням для інших і разом 3 тим самозбудженням. Там, де цього немає, напевно, погано ідуть справи із тією освітою, яку одержують від нього інші» [1, с. 421].

Аналогічні думки знаходимо у працях вітчизняних дидактів, зокрема, О. Духновича та С. Русової. Про потребу самовдосконалення, яка повинна бути в серці кожного педагога, пише О. Духнович, підкреслюючи, що культурнопросвітня діяльність учителя не може обмежуватися однією школою, а має поширюватися й на тих, хто поза нею. Важливо, щоб учитель спрямовував пізнавальні сили учня на засвоєння тих видів діяльності, які зможуть забезпечити його подальше існування й сам удосконалювався в них. С. Русова на сторінках «Дидактики» зауважує, що позитивні результати процесів розвитку й освіти особистості залежать від самостійної пізнавальної діяльності всіх учасників процесу навчання, яка спрямовується на засвоєння знань.

Свого розквіту утилітарно-функціональний підхід набуває на тлі педагогіки позитивізму та прагматизму. Г. Спенсер звертає увагу на те, що сприйняття навколишнього світу менш активоване під час навчання, орієнтованого на запам'ятовування чужих слів, заучування незрозумілого, унаслідок чого губляться природна зацікавленість пізнанням нового, активність, прагнення до самостійного набуття знань. Для педагогіки прагматизму розвиток пізнавальної самостійності індивіда є стрижневою проблемою, зусилля Дж. Дьюї та його послідовників спрямовані на створення так званого «супровідного навчання», яке всіляко розвиває самостійність особистості. При цьому зміст навчання засвоюється як «побічний продукт» під час пізнання й дослідження проблемного середовища, що організовується як логічний ланцюг пізнавальних педагогічних ситуацій. Мета такого навчання - «становлення системи внутрішньої особистісної орієнтації». Порівнюючи «традиційну» та «прогресивну» системи освіти, Дж. Дьюї висвітлює нові для його часу змістові аспекти пізнавального саморозвитку вчителя: в освіті традиційній «від учителя не вимагалося бути добре ознайомленим 3 матеріальними, історичними, економічними, житловими умовами місцевої громади, щоб 
використати їх як освітні ресурси. Для того, щоб відповідати своєму принципові, система освіти, заснована на необхідному зв'язку освіти й досвіду, мусить, навпаки, постійно зважати на ці обставини. Така вимога до вчителя $\epsilon$ ще однією причиною того, що працювати в системі прогресивної освіти важче» [2, с. 457], адже педагог повинен розвивати власну пізнавальну самостійність.

М. Монтессорі, італійський лікар і дослідниця, убачала в школі лабораторію для дослідження психічних процесів дитини, вимагала наукової освіти для педагогів, розвитку в них пізнавального інтересу до всіх виявів дітей, постійного прагнення зрозуміти природу дитини, «педагог, який свідомо ставиться до своєї роботи, міг би робити тут (мається на увазі- у «будинках дітей») важливі спостереження над індивідуальною психологією, педагог перетворюється на психолога. Тому такою важливою $\epsilon$ наукова підготовка викладача» [5]. Розвиток пізнавальної самостійності педагога за такого підходу зумовлено практичними потребами забезпечення якості навчального процесу.

3 позиції формування пізнавальної самостійності майбутніх учителів цікавим $є$ той факт, що саме в межах утилітарно-функціонального підходу висловлено думку про мету освіти як самостійного оволодіння досвідом (у тому числі - досвідом пізнавальної діяльності), уміння розв'язувати практичні завдання, висувається вимога виховання смаку педагога й учнів до самонавчання та самовдосконалення. Нині утилітарно-функціональний підхід $\epsilon$ актуальним у вітчизняному освітньому просторі.

Третій підхід до розв'язання проблеми формування пізнавальної самостійності вчителя - теоретико-методологічний. Цей підхід пов'язаний із теоретичним осмисленням досягнень минулих поколінь, узагальненням і систематизацією накопиченого досвіду та розробленням методології формування пізнавальної самостійності майбутнього вчителя у різних видах діяльності. Як відомо, процесуальний характер навчання висвітлив у своїх працях ще Я. Коменський, саме йому належить думка про те, що предметом педагогіки як науки є вивчення здатності учня до пізнання та пошук таких способів навчання, які відповідають цим здібностям і тим знанням, якими учень оволодіє в майбутньому. Головне завдання педагог убачав не в тому, щоб озброїти вчителів комплексом педагогічних рецептів, а в тому, щоб надати теоре- 
тичну основу для розгляду всіх дидактичних питань. Звідси наукове обгрунтування провідних принципів навчання, розуміння значення самостійності учнів в оволодінні знаннями, уміннями й навичками: «Юнацтво повинно сприймати освіту не ту, що задається, а істинну, не поверхневу, а міцну, тобто, щоб розумна істота - людина - привчалася керуватися не чужим розумом, а своїм власним, не тільки вичитувати 3 книг і розуміти чужі думки про речі або навіть заучувати й відтворювати їх у цитатах, але й розвивати в собі здібність проникати в корінь речей і виробляти істинне розуміння їх і оперування ними...» [4, с. 123]. Завдяки плідній теоретичній і практичній діяльності Я. Коменського стає зрозумілим, що розум і воля індивіда, його самостійність $є$ основними рушійними силами навчального процесу.

На вітчизняних теренах проблему необхідності встановлення зв'язків між теорією та практикою навчання формулює й досліджує К. Ушинський. «Якщо педагогіка хоче виховувати людину на всіх рівнях, то вона повинна попередньо пізнати iі також» [7, с. 150] - ця фраза видатного педагога може слугувати точкою відліку наукових досліджень, пов'язаних із розвитком пізнавальної самостійності як наукової проблеми. К. Ушинським розроблено проект учительських семінарій, який був в основному реалізований через земства, сформульовано принципи підготовки педагогів-фахівців. На його думку, у навчально-виховному процесі семінарій повинен переважати принцип самостійності; класні уроки повинні бути тільки перевіркою самостійних занять і керівництвом для них. К. Ушинський виокремлював основні структурні одиниці професійної освіти педагогів і підкреслював, що підготовку вихованців семінарії можна вважати якісною, якщо вона формує в них потяг до все більш високих професійних знань; виховує переконання в тому, що лише постійна подальша робота над собою, оновленням своїх педагогічних знань зробить їх справжніми вчителями. Педагогічна діяльність - це перше й найвище мистецтво тому, що вона може практично задовольнити величезну потребу людини та людства - прагнення до вдосконалення у самій природі людини [7].

Саме К. Ушинський збагатив дидактику концепцією про пізнавальну самостійність, висловивши твердження, що навчання, як окремий вид діяльності, обов'язково включає 
самостійну працю студентів із засвоєння професійних знань. У педагогічній науці він виокремлює предмет i мету самостійної діяльності студентів у професійній освіті. Практична професійна освіта, на його думку, повинна забезпечити цілісну теоретичну та методичну підготовку фахівця. Педагог на сторінках своїх творів надає практичні поради щодо фахового вдосконалення майбутнього вчителя, наполягаючи на тому, що будь-які педагогічні факти мають цінність лише тоді, коли вони аналізуються, узагальнюються, усвідомлюються та пов'язуються 3 теорією. «Педагогічні факти не є досвідом. Вони повинні справити враження на розум вихователя, перетворитися на думку, і вже ця думка, що виводиться $з$ досвіду, а не сам досвід, передається», [7] зауважує він.

У XX ст. ці рекомендації були творчо осмисленими та використаними у практичній діяльності В. Сухомлинського, який спрямував обсяг методичних вказівок на підготовку такого вчителя, який би прагнув постійно самовдосконалюватися [6], міг збільшити частку розумової праці школяра, навчити його розум трудитися, збудити в учнів любов до розумової праці. «Навчити дитину вчитися, дати їй уміння, за допомогою яких вона буде самостійно підніматися зі сходинки на сходинку довгого шляху пізнання, - це одне $з$ найскладніших завдань учителя. Мислителем ваш вихованець стане лише тоді, коли ви приходите до нього 3 думкою, запалюєте його своєю допитливістю, спрагою й ненаситністю пізнання, передаєте йому почуття гордості мислителя» [6].

У другій половині XX ст. під впливом соціальних факторів (зміцнення зв'язку зі школою, перегляду змісту освіти, успіхів науково-технічної революції і досягнень психології) теорія пізнавальної самостійності значно збагатилася: подано характеристику суті поняття «пізнавальна самостійність»; визначається компонентний склад даного поняття; у 80-х та 90-х роках, у результаті проведення значної кількості групових психолого-педагогічних досліджень, пізнавальна самостійність в освіті набула науково вивченого пояснення й обгрунтування. Найбільш повним утіленням теоретикометодологічного підходу до розв'язання проблеми формування пізнавальної самостійності вчителя можуть слугувати праці В. Лозової, Т. Шамової та інших педагогів. Визначене місце пізнавальної самостійності в складній структурі 
професійної підготовки майбутніх педагогів до професійної діяльності. Нині саме теоретико-методологічний підхід $\epsilon$ домінантним у наукових дослідженнях, присвячених проблемі формування пізнавальної самостійності індивіда.

На сучасному етапі розвитку педагогічної освіти можна поставити питання про необхідність вивчення пізнавальної самостійності майбутнього вчителя як цілісної категорії. Аналіз виокремлених підходів доводить, що існує реальна необхідність у цілеспрямованому вивченні шляхів і засобів формування пізнавальної самостійності майбутніх учителів.

\section{Література}

1. Дистервег А. Посібник для освіти німецьких учителів / Фрідpix Адольф Вильгельм Дистервег // Історія зарубіжної педагогіки. Хрестоматія / [уклад. С. Коваленко, Н. Бєлкіна]. - К. : Центр навчальної літератури, 2008. - С. 360-424. 2. Дьюї Дж. Школа і суспільство / Джон Дьюї // Історія зарубіжної педагогіки. Хрестоматія / [уклад. Є. Коваленко, Н. Бєлкіна]. - К. : Центр навчальної літератури, 2008. - С. 449-463. 3. Квінтіліан М. Ф. Про виховання оратора // Історія зарубіжної педагогіки. Хрестоматія / [уклад. С. Коваленко, Н. Бєлкіна]. - К. : Центр навчальної літератури, 2008. - С. 48-58. 4. Коменский Я. А. Избранные педагогические сочинения : в 2-х т. - Т. 1 : Великая дидактика / Ян Амос Коменский / [ред. и вводн. ст., прим. проф. А. А. Красновского]. - М. : Учпедгиз, 1982. - 520 с. 5. Монтессори М. Метод наукової педагогіки // Історія зарубіжної педагогіки. Хрестоматія / [уклад. Є. Коваленко, Н. Бєлкіна]. - К. : Центр навчальної літератури, 2008. - С. 186-201. 6. Сухомлинський В. О. Вибрані твори : в 5-ти т. / Василь Олександрович Сухомлинський; [ред. кол. А. Г. Дзеверін та ін. ]. - К. : Рад. школа, 1979. - Т. 3. - 719 с. 7. Ушинский К. Д. Педагогические статьи 1857-1961 гг. // Собрание сочинений : в 11 т. / Константин Дмитриевич Ушинский; [ред. А. М. Еголина, Е. Н. Медынского, В. Я. Струминского]. - М.; Л. : АПН РСФСР, 1949. - Т. 2. - 656 с. 